Brit. F. vener. Dis. (1969), 45, 241.

\title{
INFLUENCE OF pH ON VAGINAL DISCHARGES*
}

\author{
BY \\ LESTER COHEN \\ Department of Venereology, Cardiff Royal Infirmary
}

The fluid content of the vagina is derived solely from:

(1) Mucus secretions of the cervical columnar cells.

(2) Transudation through the vaginal walls.

(3) Vulval secretions from sebaceous and sweat glands.

(4) Bartholin's glands, which are said to produce an "acid mucus secretion".

Vaginal acidity is thought to depend on the presence and amount of lactic acid formed by the action of Döderlein's bacilli on the glycogen of the epithelial cells lining the vagina.

Most pathogenic bacteria have a fairly restricted $\mathrm{pH}$ range and grow best at a $\mathrm{pH}$ of about $7 \cdot 5$. This may be a reflection of the fact that mammalian tissue and blood have a $\mathrm{pH}$ of this order. For example, the pneumococcus has an optimal $\mathrm{pH}$ of $7 \cdot 8$ and a growth range of $7 \cdot 3$ to $8 \cdot 3$. Commensal and saprophytic bacteria have a much wider growth range. $E$. coli has an optimum $\mathrm{pH}$ of 6.5 but a growth range of $4 \cdot 4$ to $7 \cdot 8$. Yeasts and fungi generally have an optimum acid $\mathrm{pH}$ and may grow at a $\mathrm{pH}$ of 2 and lower (Stephenson, 1949). Many of the published data on the $\mathrm{pH}$ effects on growth are vitiated because they take into account only the initial $\mathrm{pH}$ of the reaction, and also because of inaccurate readings due to inadequate or poorlyhandled equipment. The $\mathrm{pH}$ changes so rapidly that the final $\mathrm{pH}$ of a reaction may be far removed from that at the start especially where fermentable carbohydrates are present. The reaction at which an organism is grown profoundly affects its enzyme make up; thus, although $E$. coli will grow at $\mathrm{pH}$ 4.5 to 9 (Gale and Epps, 1942), its optimal growth is strictly governed by the $\mathrm{pH}$ of optimal activity of the enzymes concerned with nitrogen metabolism

$\star$ Received for publication July 24, 1968.
(Gale, 1940). Thus, measurement of oxidation reduction potential would be a more accurate reflection of the state of affairs than would $\mathrm{pH}$.

For practical purposes in clinical studies, accurately determined $\mathrm{pH}$ values taken under constant conditions have been taken as an acceptable standard of measurement in relation to bacterial, fungal, and protozool activity.

Average vaginal $p H$ values quoted in standard text books

$\begin{array}{ll}\text { Newborn } & 5 \cdot 7 \\ \text { Children } & 6 \text { to } 8 \\ \text { Puberty } & 4 \cdot 0 \\ \text { Pregnancy } & 4 \cdot 0 \\ \text { Menopause } & 7 \cdot 0 \\ \text { Mean pH in the } & 5 \cdot 5, \text { falling during ovulation } \\ \quad \text { child-bearing age } & \end{array}$

Optimal growth $\mathrm{pH}$ of some common organisms

$\begin{array}{ll}\text { Trichomonas vaginalis } & \left\{\begin{array}{c}4.9 \text { to } 7 \cdot 5 \text { (text-books) } \\ 3.6 \text { to } 4 \cdot 7 \text { (Feo, 1956) } \\ 5 \cdot 8 \text { to } 6 \cdot 4 \text { (Lumsden, } \\ \text { Robertson, and } \\ \text { McNeillage, 1966) }\end{array}\right. \\ \text { Candida albicans } & 5 \cdot 4 \\ \text { N. gonorrhoeae } & 7 \cdot 5 \\ \text { B. proteus } & 7 \cdot 4 \\ \text { Streptococci } & 7 \cdot 4 \\ \text { Diphtheroids } & 7 \cdot 2\end{array}$

\section{Equipment}

A standard model $23 \mathrm{~A}$ reading $\mathrm{pH}$ meter supplied by E.I.L. was used for these studies. Continuous indication is given of the $\mathrm{pH}$ value of the liquid under test so that rapidly changing conditions may be followed without difficulty. The machine is fundamentally an ultrastable d.c. amplifier having an exceptionally high input resistance. The output is graduated directly in $\mathrm{pH}$ units from 0 to 14 , and it is possible with this machine to read accurately to $0.05 \mathrm{pH}$. The basic stability of the machine is such that zero drift under normal operating conditions 


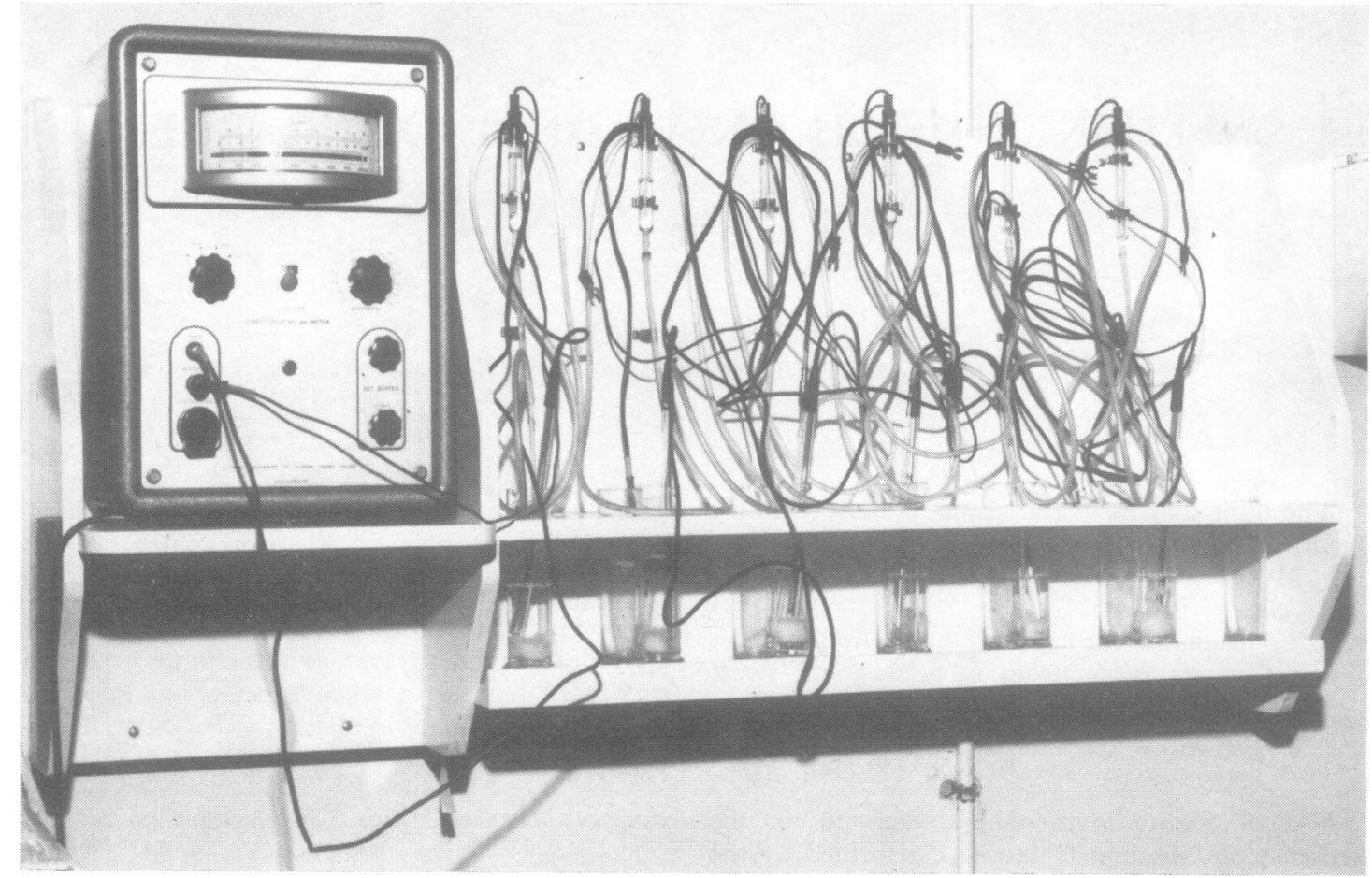

FIG. 1.-Equipment wall-mounted for clinical use.

will not exceed $0.02 \mathrm{pH}$ for periods of 24 hours or more (Fig. 1). All supply voltages are stabilized within the instrument so that its readings remain substantially unaffected by variations in the power line voltage. For use within the vagina the electrodes were designed so that they consisted of a cylinder of silverized glass $23 \mathrm{~cm}$. long and $0.5 \mathrm{~cm}$. in diameter, the contact end of zintered glass being $0.5 \mathrm{~cm}$. in diameter. The calomel reference electrode containing saturated potassium chloride solution was connected by inert tubing to a hollow glass tube $25 \mathrm{~cm}$. long and $0.2 \mathrm{~cm}$. in diameter with a calomel plug at its distal end. The silverized glass electrode had platinum wire running through its length should measurement of oxidation reduction potential be required (Fig. 2, opposite).

This model incorporates a fully automatic temperature compensating mechanism. However, as the temperature of the buffer solution used was prepared and kept at body temperature in a thermostat-controlled jacket and all readings with the machine took place under constant temperature conditions in a draught free centrally heated lroom at $73^{\circ} \mathrm{F}$., there was no need to use the isopotential temperature control system, and a dummy plug resistance supplied with the set was inserted into the machine as the thermometer was not in use.

The electrodes were prepared for use and stood at all times when not in use in sterile distilled water. Two buffer solutions of known $\mathrm{pH} 4$ and 9 were made up using buffer tablets supplied by Burroughs Wellcome and Co. and closely observing the following points:

(1) The distilled water was freed of carbon dioxide by boiling.

(2) The solution was accurately measured to $50 \mathrm{ml}$. on making up.

(3) Contamination of the solution with potassium chloride was scrupulously avoided as neutral salts would affect the $\mathrm{pH}$.

With the selector switch set at $\mathrm{pH} 0$ to 14 . the electrodes were immersed in the buffer solution of known $\mathrm{pH}$, the set buffer controls were adjusted until the machine read the correct $\mathrm{pH}$ value of the buffer solution on the control scale. For initial settings, the makers of the equipment suggest that the electrodes be checked against buffered solutions of known $\mathrm{pH} 4$ and 9 before use, thoroughly rinsing the electrodes in distilled water between measurements.

\section{Method}

In clinical use, the $\mathrm{pH}$ meter with six sets of electrodes were mounted on a specially designed wall fixture at the right-hand side of the foot of the couch. Each set of electrodes was kept permanently immersed in $100 \mathrm{ml}$. cylinders containing sterile distilled water with cotton wool pads at the bottom of the jars to prevent damage to the zintered glass. Each cylinder containing distilled water was duplicated by another containing 1 in 1,000 


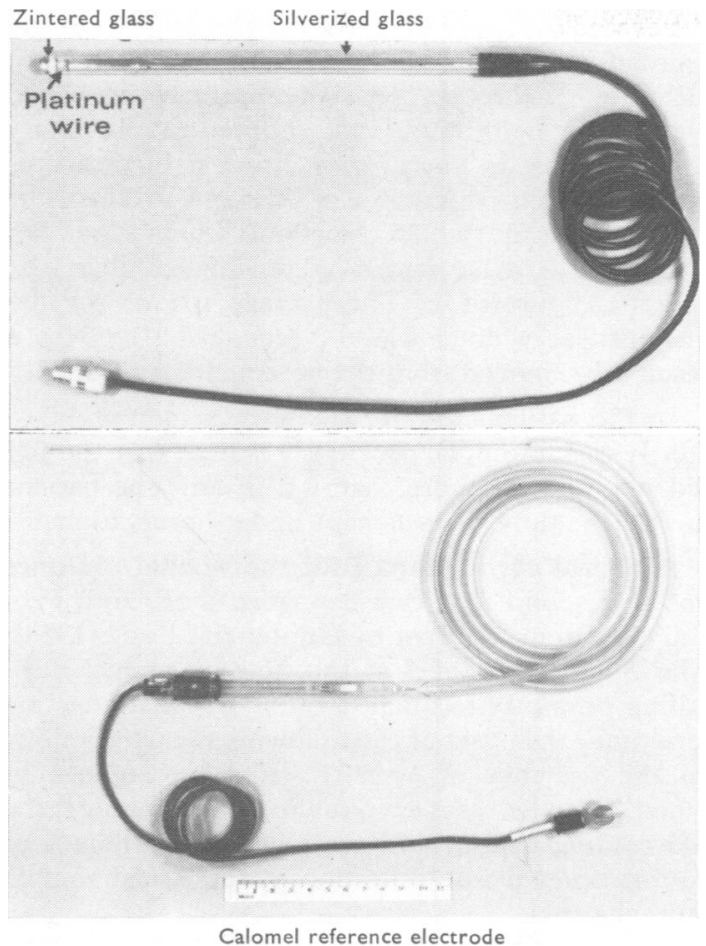

Fig. 2.-Electrodes (detail).

aqueous solution of hibitane. It had previously been found that sterilization of the electrodes in 1 in 1,000 hibitane was the only practical way of avoiding crossinfection and of ensuring that the electrodes were sterile without damaging them. After use, the electrodes were cleaned of contaminating debris and immersed in the hibitane solution for at least 30 minutes. Subsequent incubating of culture media failed to show growth of any bacteria, fungi, or protozoon. Both the distilled water and the hibitane solution were changed twice weekly.

With the patient in the lithotomy position, an unlubricated Cusco speculum was passed, and the cervix displayed as quickly as possible. The balanced electrodes were inserted into the vagina, taking great care to see that they did not touch anything other than the epithelium at the back of the cervix on which the ends were placed in contact. The $\mathrm{pH}$ was read directly and the electrodes replaced at once into the hibitane solution after removing debris with gauze. After not less than 30 minutes the electrodes were replaced in buffer solutions for further balancing. With six sets of electrodes in constant use, we have found that there is no danger of using a contaminated electrode. It has been my practice to balance the electrodes every time before use in buffer solutions of $\mathrm{pH} 4$ and 9, thus hoping to ensure absolute accuracy of readings.

At this stage the factors affecting the degree of ionization of a solution must be briefly considered as these will influence the accuracy of the $\mathrm{pH}$ readings.

The readings depend on:

(1) Concentration of the liquid under test;

(2) Volume of liquid available for analysis;

(3) Carbon dioxide tension at the time of measurement;

(4) Temperature;

(5) Speed of operation.

For practical purposes, the concentration and the volume of the "liquid" under test were constant. There was always sufficient volume of liquid under test conditions for analysis with such a machine. The carbon dioxide tension in the posterior fornix will be constant for each reading provided that the whole operation is carried out speedily. The average time taken to register the reading was in fact $10 \mathrm{sec}$. and the response time of the machine was $3 \mathrm{sec}$. There is no variation in temperature from patient to patient that would cause any significant difference in $\mathrm{pH}$. Provided all the above factors are controlled, the $\mathrm{pH}$ readings should be accurate with such equipment to $0 \cdot 1$.

\section{Clinical Material}

The conditions diagnosed in 200 women (average age 23 years) are shown in Table I. There were 44 cases of gonorrhoea, 58 of infection with $C$. albicans, 42 of vaginitis due only to infestation with $T$. vaginalis, and 56 with essentially normal findings. If those with $T$. vaginalis infestation associated with other venereal infection are added, there were 85 women with trichomonal infestation. In this series

TABLE I

PREGNANCY AND MARITAL STATUS RELATED TO VAGINAL INFECTION

\begin{tabular}{|c|c|c|c|c|c|c|}
\hline \multirow{2}{*}{ Diagnosis } & \multirow{2}{*}{ No. } & \multirow{2}{*}{ Combined Condition } & \multirow{2}{*}{ No. } & \multirow{2}{*}{ Pregnant } & \multicolumn{2}{|c|}{ Unmarried } \\
\hline & & & & & No. & Per cent. \\
\hline Gonorrhoea & 44 & $+T$. vaginalis & 30 & 1 & 28 & 66 \\
\hline Non-venereal & 56 & & & 3 & 28 & 50 \\
\hline C. albicans & 58 & $+T$. vaginalis & 13 & 20 & 12 & 20 \\
\hline$T$. vaginalis & 42 & & & 1 & 31 & 80 \\
\hline Total & 200 & & 43 & $25(12.5$ per cent. $)$ & 99 & 50 \\
\hline
\end{tabular}

Total with Trichomonas vaginalis $42+30+13=85$. Total with combined pathology $30+13=43$. 
twenty women with candidiasis were pregnant, all of them married.

Of the total number examined, 50 per cent. were pregnant.

\section{Findings}

The distribution of vaginal $\mathrm{pH}$ in the whole series of 200 women is shown in Fig. 3, and these values are related to the diagnosis and average age in Table II.

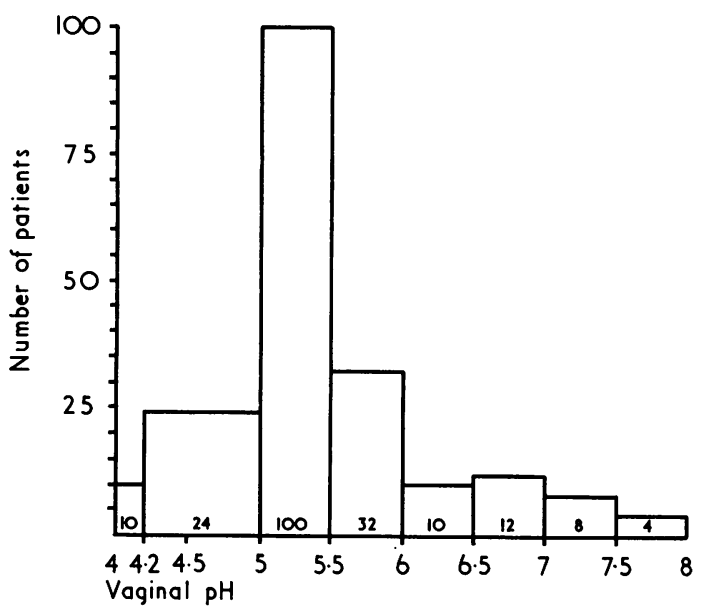

FIG. 3.-Distribution of vaginal pH in a series of 200 women.

TABLE II

VAGINAL PH VALUES RELATED TO DIAGNOSIS

\begin{tabular}{|c|c|c|c|c|}
\hline \multirow{2}{*}{ Diagnosis } & \multirow{2}{*}{ No. } & \multicolumn{2}{|c|}{ pH } & \multirow{2}{*}{$\begin{array}{c}\text { Average } \\
\text { Age (yrs) }\end{array}$} \\
\hline & & Mean & Range & \\
\hline Gonorrhoea & 44 & $5 \cdot 2$ & $4 \cdot 2-7 \cdot 5$ & 22 \\
\hline Non-venereal & 56 & $5 \cdot 7$ & $4 \cdot 0-8 \cdot 0$ & 21 \\
\hline C. albicans & 58 & $4 \cdot 8$ & $4.0-5.5$ & 26 \\
\hline T. vaginalis & 42 & $5 \cdot 2$ & $4 \cdot 0-7 \cdot 0$ & 30 \\
\hline
\end{tabular}

The average vaginal $\mathrm{pH}$ of the women suffering from gonorrhoea was $5 \cdot 2$ (range $4 \cdot 2$ to $7 \cdot 5$ ).

This figure is nowhere near the optimal pH of growth of the organism which is $7 \cdot 5$. The average $\mathrm{pH}$ of those suffering from vaginal candidiasis is nearer the accepted mark, being 4.8 (range 4.0 to $5 \cdot 5$ ), the lowest average value of this series. In this group infestation with $T$. vaginalis was commoner in the slightly older women.

The highest recorded $\mathrm{pH}$ in this series was 8 and the lowest $4 \cdot 0$. In the absence of blood in the vagina, the average variation in $\mathrm{pH}$ in any one patient did not exceed $0 \cdot 2$, over a period of 3 to 6 months at any time of the menstrual cycle and irrespective of infection, treatment, type of contraceptive used, type of underclothing worn, and nature of sanitary protection used. The average number of measurements on each patient was 7 (range 4 to 11 ). The average $\mathrm{pH}$ of the 25 pregnant women was 5.5 (range 8 to $4 \cdot 1$ ), which is far higher than the accepted figure of 4 . The average $\mathrm{pH}$ of the ten menopausal women was $5 \cdot 2$ (range 4.2 to 5.5 ), a result far removed from the accepted figure of 7 .

In 156 patients the $\mathrm{pH}$ lay in the region of 4.2 to 6.0 It was found, as previously stated, that the $\mathrm{pH}$ did not vary by more than 0.2 in any one patient during the time she was kept under observation.

A typical cyclic pattern for the vaginal $\mathrm{pH}$ does not correspond with that described by Rakoff, Feo, and Goldstein (1944) or by Hunter and Long (1958), who found a $\mathrm{pH}$ of 7 at the time of vaginal flow, falling promptly to 5 and tending to remain at this level until the onset of the following menstrual flow. In the presence of even the slightest amount of blood, in some cases even microscopic amounts, the $\mathrm{pH}$ reading is always in the region of 7 . This is of course never a true reflection of the actual vaginal epithelial $\mathrm{pH}$.

The average $\mathrm{pH}$ values in the different age groups (Table III) in this series did not vary by more than 0.9 . No children under the age of 10 years were available in this series and no women over the age of 50 years in statistically significant numbers. However, there was nothing in these figures to suggest that in any given person there might be a variation of vaginal $\mathrm{pH}$ as wide as from 4 to 8 from birth to menopause including pregnancy. There is no evidence to support the accepted vaginal $\mathrm{pH}$ as being 4 at puberty, 4 during pregnancy, and 8 at the menopause.

TABLE III

VAGINAL pH VALUES RELATED TO AGE

\begin{tabular}{|c|c|c|c|}
\hline \multirow{2}{*}{ Age Group } & \multirow{2}{*}{ No. of Patients } & \multicolumn{2}{|c|}{$\mathrm{pH}$} \\
\hline & & Mean & Range \\
\hline $10-20$ & 36 & $5 \cdot 7$ & $4-80$ \\
\hline $20-30$ & 84 & $4 \cdot 8$ & $4-6.0$ \\
\hline $30-40$ & 62 & $5 \cdot 2$ & $4-7 \cdot 0$ \\
\hline $40-50+$ & 18 & $5 \cdot 2$ & $4-6.5$ \\
\hline
\end{tabular}

Table IV relates severity of symptoms to vaginal $\mathrm{pH}$. It is clear that the women with the most severe symptoms and signs were those with the 
TABLE IV

VAGINAL PH RELATED TO SEVERITY OF INFECTION

\begin{tabular}{c|c|c|c}
\hline \multicolumn{1}{c|}{ Severity of Symptoms } & $\begin{array}{c}\text { No. of } \\
\text { Cases }\end{array}$ & Mean & Range \\
\hline $\begin{array}{c}\text { Asymptomatic, without vaginitis or } \\
\text { discharge }\end{array}$ & 56 & 5.9 & $4-8.0$ \\
\hline $\begin{array}{c}\text { Asymptomatic, with slight discharge } \\
\text { but no vaginitis }\end{array}$ & 34 & 5.7 & $4-7.5$ \\
\hline $\begin{array}{c}\text { Complaint of discharge, which is } \\
\text { profuse but without vaginitis }\end{array}$ & 64 & 4.8 & $4-5.5$ \\
\hline $\begin{array}{c}\text { Complaint of discharge and irritation; } \\
\text { profuse discharge with definite } \\
\text { vaginitis }\end{array}$ & 48 & 4.4 & $4-5.5$ \\
\hline
\end{tabular}

lowest vaginal $\mathrm{pH}$. This does not appear to be due to their infections causing a lowering of vaginal $\mathrm{pH}$ (see Table II).

Cytologically, the patient with a low vaginal $\mathrm{pH}$ exhibits a vaginal aspirate rich in polymorphonuclear leucocytes, and a clustering of polymorphs around the epithelial cells may be observed. There may also be excessive maturation of the epithelial cells, and there is an impression of hyperchromasia. This condition may be due to increased vascularity (Koss and Durfee, 1961). Considerably more epithelial cells are found in those patients with a low vaginal $\mathrm{pH}$. There may also be an increase in the size of the nuclei, but they retain their normal structure. It is of considerable importance to note that a low vaginal $\mathrm{pH}$ may exist in the relative absence or even total absence of Döderlein's bacilli, and it is suggested that the $\mathrm{pH}$ of the vagina depends on the degree of fermentation between the glycogen of the shed epithelial cells and the cervical mucus secretion. This would explain the increased morbidity in patients with a low vaginal $\mathrm{pH}$ in the presence of primary vaginal infections. The cytological picture of the vaginal exudate of the patient with a low vaginal $\mathrm{pH}$ corresponds to that found in women taking oral contraceptives, in diabetics, in pregnant women, and in those taking oral steroids. It seems reasonable to assume that, if excessive epithelium is being shed, invasion of the deeper layers may occur by normally benign saprophytic organisms which then will become "pathogenic".

It is suggested that any condition that increases the amount of cervical secretion or desquamation of vaginal epithelium may give rise to a primary vaginal discharge where the causative organism is able to penetrate through epithelial deficiencies. During this investigation it has been found that the woman with a low vaginal $\mathrm{pH}$ is in the first instance relatively resistant to treatment of a vaginal discharge; she is typically the patient who may require a second course of metronidazole for trichomoniasis or prolonged treatment for candidiasis. Conversely, the woman with a high vaginal $\mathrm{pH}$ may harbour yeasts or trichomonads and yet remain symptomless.

\section{Summary}

200 women, some with no genital disease, others with gonorrhoea, candidiasis, or trichomonal vaginitis, were studied by repeated measurements to determine possible variations in value of the vaginal $\mathrm{pH}$. The principal finding was that each woman has a vaginal $\mathrm{pH}$ which remains stable within narrow limits and may only be altered, as far as present investigations show, by the administration of steroids. The $\mathrm{pH}$ does not appear to depend on the menarche, pregnancy, the menopause, illness, or the administration of other drugs. It is suggested that vaginal acidity depends on the amount of fermentation taking place between the glycogen-containing epithelial cells and the cervical mucus. It is possible that this amount of desquamation is regulated by the quantity of circulating oestrin. The woman with a low vaginal $\mathrm{pH}$ is more liable to increased morbidity from otherwise nonpathogenic saprophytic organisms and others causing primary vaginal discharges. This appears to be due to the excessive desquamation in those with a low vaginal $\mathrm{pH}$ causing a break in continuity of the epithelium, breaching the protective layers, and allowing penetration by the organisms.

\section{REFERENCES}

Feo, L. G. (1956). Amer. F. trop. Med. Hyg., 5, 786.

Gale, E. F. (1940). Bact. Rev., 4, 135.

—, and Epps, H. M. R. (1942). Biochem. F., 36, 600.

Hunter, C. A., JR., and Long, K. R. (1958). Amer. f. Obstet. Gynec., 75, 872.

Koss, L. G., and DuRfeE, G. R. (1961). "Diagnostic Cytology and its Histopathologic Bases", p. 60. Lippincott, Philadelphia.

Lumsden, W. H. R., Robertson, D. H. H., and MCNeillage, G. J. C. (1966). Brit. f. vener. Dis., 42, 145.

Rakoff, A. E., Feo, L. G., and Goldstein, L. (1944). Amer. F. Obstet. Gynec., 47, 467.

Stephenson, M. (1949). "Bacterial Metabolism", 3rd ed., pp. 97-98. Longmans Green, London. 
Influence de $\mathbf{p H}$ sur les pertes vaginales

\section{RÉSUMÉ}

200 femmes, quelquesunes indemmes d'affection génitale, d'autres atteintes de gonococcie, de candidose ou de vaginite à trichomonas, furent l'objet de mesures répétées pour mettre en évidence des variations possibles de la valeur du $\mathrm{pH}$ vaginal. La principale constatation est que chaque femme a un $\mathrm{pH}$ vaginal qui reste stable dans d'étroites limites et qui peut seulement être changé, autant que le montre la présente recherche, par l'administration de stéroïdes. Le $\mathrm{pH}$ n'apparaít pas dépendre de la menstruation, de la grossesse, de la ménopause, de maladies ou de l'administration d'autres médicaments. Il est suggéré que l'acidité vaginale dépend de l'importance de la fermentation qui se développe entre les cellules épithéliales chargées de glycogène et le mucus cervical. Il est possible que cette importance de la desquamation soit sous la dépendance de la quantité d'oestrine circulante.

Une femme à $\mathrm{pH}$ bas est plus exposée à la majoration de troubles morbides à partir de germes saprophytes non pathogènes ou d'autres responsables du début des pertes vaginales. Ceci semble être dû, chez celles à bas $\mathrm{pH}$, à une desquamation excessive créant une solution de continuité de l'épithélium, rompant les couches protectrices et permettant la pénétration des germes. 


\section{APPENDIX}

PROFORMA USED IN THE INVESTIGATION

NO...... AGE..... RESIDENTIAL AREA..... OCCUPATION..... SIBS (......Sisters ...... Brothers)

MARITAL STATUS Married/Single/Widowed/Divorced

PREVIOUS DISCHARGES AND TREATMENT

SANITARY PROTECTION External/Internal UNDERCLOTHING Nylon/Cotton

CONTRACEPTIVE USED

MENARCHE.

CYCLE

OBSTETRIC HISTORY

DRUGS TAKEN IN PAST YEAR

SEXUAL EXPERIENCE Marital/Extramarital

PAST HISTORY General.

Gynaecological

\begin{tabular}{|c|c|c|c|c|c|c|}
\hline Wet film & Film & Culture & $\mathrm{pH}$ & $\operatorname{Tr}$ & Date & Day of cycle \\
\hline & & & & & & \\
\hline & & & & & & \\
\hline & & & & & & \\
\hline & & & & & & \\
\hline
\end{tabular}

WR PPR GCFT OTHER SEROLOGICAL TESTS

Cervical cytology

Vulva

Bartholin's glands

Urethra

Vagina

Cervix

Rectum and anus

Lymphatics

Extragenital lesions

URINE SpGr. Alb. Sugar Blood Phosph. Bile Acetone Alkaline/Acid Casts Cells Deposits TREATMENT AND PROGRESS

FINAL DIAGNOSIS AND OBSERVATIONS 